\title{
Opera in the Open Air
}

Author(s): M. Böhe

Source: The Musical Times, Vol. 53, No. 833 (Jul. 1, 1912), p. 456

Published by: Musical Times Publications Ltd.

Stable URL: http://www.jstor.org/stable/906903

Accessed: 05-06-2016 11:07 UTC

Your use of the JSTOR archive indicates your acceptance of the Terms \& Conditions of Use, available at

http://about.jstor.org/terms

JSTOR is a not-for-profit service that helps scholars, researchers, and students discover, use, and build upon a wide range of content in a trusted digital archive. We use information technology and tools to increase productivity and facilitate new forms of scholarship. For more information about JSTOR, please contact support@jstor.org.

Musical Times Publications Ltd. is collaborating with JSTOR to digitize, preserve and extend access to The Musical Times 
The first year at the Organ. By Percy C. Buck.

[Macmillan \& Co., Ltd. ; Stainer \& Bell, Ltd.]

This admirable work, though necessarily short, covers much ground, and should prove invaluable to the beginner in laying the foundation of a true organ style. The exercises are most skilfully written, and fulfil their various purposes in the happiest manner, while the advice given from time to time is sound and well expressed. The book will carry the pupil on quite naturally to Dr. Buck's excellent Treatise, already noticed in these columns.

\section{BOOKS RECEIVED.}

Tannhäuser and the Mastersingers of Niiremburg. Described and interpreted in accordance with Wagner's own writ'ngs by Alice Leighton Cleather and Basil Crump. Pp. 161. Price 2s. 6d. (London: Methuen.) Royal Performances in London Theatres. Compiled by Richard Northcott. (Deals with the principal command and gala representations at Drury Lane and His Majesty's Theatres, and at Covent Garden since I736.) With many illustrations. Pp. 38 . (London: Percy Lindley.)

Giacomo Puccini e lopera internazionaie. By Fausto

Torrefranca. Pp. 136. (Turin : Fratelli Bocca.)

\section{Correspondence.}

\section{OPERA IN THE OPEN AIR.}

TO THE EDITOR OF 'THE MUSICAL TIMES.'

SIR, - Will you allow me the use of your columns to announce that a holiday meeting of musicians and others especially interested in Opera has been arranged for the month of August, at Hindhead, Surrey?

The following musicians have kindly promised to lecture or assist with the performances: Madame Marie Brema (if in England), Mr. Rutland Boughton, Mr. Reginald Buckley, Mr. Gerald Cumberland, Herr Georg Gräner (musical critic of Die Vossische Zeitung) and Mr. Sydney Grew.

Apart from the general studies and holiday-making, an opera will be put into rehearsal, and performed in the open air at the end of the holiday; and I may mention that the company will have special access to a beautiful private estate of wooded hill-land.

I shall be happy to forward further particulars to musicians and amateurs who care to join us. - Yours faithfully,

Tarn Moor, Hindhead, M. BöHE, Hon. Sec. Haslemere.

\section{Obituary.}

We regret to have to record the following deaths :

Mr. C. J. DALE, which occurred on June I6, after a severe operation. He was born at Longton (Staffs) on May 9, I842. In early age he removed to Denby (Derbyshire), and here his musical proclivities were roused, and he did much to foster musical enthusiasm in the village. At the age of eighteen he came to London, and took up a business career. In the 'seventies he founded and conducted the Finsbury Choral Association, and he remained conductor for twenty years. In I 888 he founded the Metropolitan College of Music at Holloway, London, N., and he was principal of the institution until its incorporation with the London Academy of Music. Failing health led him to cease musical work during recent years. He was entirely a self-taught musician, and was always strictly an amateur. All who were brought into contact with him were impressed with his ingratiating and refined manner, and his clear-headedness. $\mathrm{He}$ had a natural pride in the success of his highly-talented son, Mr. Benjamin J. Dale, whose achievements are probably only a foretaste of greater work.
Dr. JOSEPH GORdon SAUNDERS, on June 17 , at the age of seventy-five. He took the Oxford Mus. Bac. degree in 1872 and that of Mus. Doc. in 1878 . He was educated in music privately. He was professor of harmony and pianoforte at Trinity College of Music, and he was active as an examiner. He composed many pieces in the smaller forms, and wrote the work entitled 'Examples in strict counterpoint' for Novello's 'Primer Series.' He showed high capabilities for all the tasks he undertook.

M. JAN Blockx, which occurred recently at Antwerp. $\mathrm{He}$ was born on January $25,185 \mathrm{I}$, and he studied at the Conservatoires of Antwerp, Brussels and Leipsic. $\mathrm{He}$ vecame professor at the Antwerp Conservatoire, and on the death of Peter Benoit was promoted to the post of director of that institution. He wrote a number of vocal and instrumental works, and is chiefly known by his operas 'Herbergprinses,' which is performed frequently on French and German stages, and 'La France de la Mer.'

Signor GiUlio RiCORdi, at Milan, aged seventy-one. Since I 888 he had been head of the firm of Ricordi, founded in 1808 , and notable as the publishers of many of Verdi's and all Puccini's operas.

We quote the following from The Times:-

'At Deal, on Friday, May 3, aged eighty-one, William BalF WotTon, principal bassoon of the Crystal Palace orchestra, and of all the chief musical events of his time. A unique British artist-expression, tone, execution alike perfect-one whose beautiful playing can never be forgotten by his contempories in art, and by all lovers of classical music of his day. This tribute from a friend and ardent admirer.

\section{ELGAR'S SYMPHONIES AT BIRMINGHAM}

In connection with recent performances of Sir Edward Elgar's two Symphonies at the Birmingham Promenade Concerts, under the direction of Mr. Landon Ronald, the following remarks from the pen of Mr. Ernest Newman appeared in the Birmingham Daily Post:

- The more one reflects upon these two Symphonies of Elgar the more evident it becomes that they represent an important step in the evolution of the symphonic form. Really, when we think of it, music, as Busoni contends in his suggestive brochure, "Entwurf einer neuen Aesthetik der Tonkunst," for all the wonderful things it has done in the past, is virtually only just beginning to find itself. If it be true of any art that it is the more perfect the more it suggests an improvisation, it is especially true of music. A mental comparison of the architecture of the Brahms Symphony we heard the other evening with that of Elgar's Symphonies will at once show how superior the new works are in point of freedom and naturalness of form and in the unpremeditated, unfettered transitions of their moods. Music is here getting away from the discipline of the drill-sergeant, with his insistence or evolutions ascording to rule, and acquiring the ease and elasticity of gait of the natural mian. Part of the charm of the two new works comes from the fact that their novelty of form is not the result of merely abstract speculation, but the unconscious outcome of a new way of musical thinking. They are full, too, both of beauty and of style. I doubt whether there is so beautiful a slow movement as that of Elgar's first Symphony to be found in the whole range of symphonic literature; while the whole work teems with consummately managed points of style.

We hear that a volume of 'Reminiscences, impressions and anecdotes' by Mr. Francesco Berger, now in the press, will be issued in September by Messrs. Sampson Low, and that Queen Alexandra has graciously accepted the dedication.

The King and Queen have consented to be present at Queen's Hall on July 23, when the orchestral concert of the Koyal College of Music Patron's Fund will be given.

It is proposed to commemorate the life and work of the late Dean of St. Paul's, Dr. Gregory, by the foundation of a scholarship at the Cathedral Choir School to be called 'The Dean Gregory Memorial Scholarship. 